\title{
Investigating the effect of apple pomac silage as fodder source on performance and residues of its toxins in milk and some rumen fermentation in Mahabadi lactation goats in early lactation period
}

\author{
A. G. Gharehbagh ${ }^{1 *}$, R. Pirmohammadi², Y. A. Alijoo ${ }^{2}$, H. K. Behroozyar ${ }^{2}$ \\ ${ }^{1}$ Department of Agriculture Science, Payame Noor University (PNU), P.O Box, 19395-4697, Tehran, \\ Iran. \\ ${ }^{2}$ Department of Animal Science, Agriculture Faculty, Urmia University, Urmia, Iran.
}

E-mail: ahadgolghasemgharehbagh@gmail.com

Received: 10.02.2020 Accepted 06.03.2020

\begin{abstract}
The aim of this study was to evaluate effect of apple pomace silage as fodder source on performance and residues of its toxins in milk and some rumen fermentation in Mahabadi lactation goats in early lactation period. There was no significant difference within treatments apple pomace mixed silage had no effect on dairy goat's average daily feed intake. There were no significant differences about $\mathrm{pH}$ changes between treatments. The protozoa population tended to decrease and ammonia nitrogen has increased significantly in different treatments $(P \leq 0.05)$. According to the increase of volatile fatty acids production, the proportion of acetatenot differed even though that of Propionate and iso-butyrate increased but none significantly. The molar ratios of acetate and propionate and iso-butyratein the goats rumen containing apple pomace was differed in respect to the availability for fermentation by rumen microflora. In regard to this information, the inclusion of apple pomace silage in experimental goat's diet was associated with a slight lower rumen $\mathrm{pH}$, higher concentration of acetate and propionate and total volatile fatty acids in rumen. The potential value of byproducts in animal feeding and better dry matter and organic matter digestibilitydepends on their nutritive characteristics. But the livestock producers are responsible for ensuring that the animals and products that they market do not contain unacceptable chemical residues. Anyone intending to feed waste materials to ruminant animals such as cattle, sheep and goatsor to pigs must ensure that it is free of prohibited or restricted substances.
\end{abstract}

Key words: Apple pomace silage; Toxins residues; Rumen fermentation; Lactation goats

\section{Introduction}

Byproducts from the food industry can be utilized as feed for small ruminants such as goats and sheep to the benefit of both farmers and animals. Furthermore, the utilization of the byproducts can reduce waste production from the fruit industry, and thus also improve the resource efficiency to the good of the environment. The inclusion of industrial byproducts such as citrus pulp in the composition of animal diets has been widely recommended due to sustainability aspects and their high level of carbohydrates. Notwithstanding low nitrogen and high free sugar content whose fermentation in the rumen may eventually lead to alcoholaemia, apples (Malus domestica) as an alternative feed for cattle, sheep and goats and have also been considered to help solving the economical disposal of industrial residues and fruits without the required characteristics to commercialization. Studies showed that apple pomac supplemented with natural protein was comparable toprotein enriched corn silage.

Apple contains about 12 percentage carbohydrate, most of which is inthe form of readily fermentable carbohydrates such as glucose, fructose and sucrose. 30 or 40 percent of total world production of apples are broken, damaged,culled, dropped and therefore not marketed. Also 20 or 40 percent of them are processed for juice extraction. The residue left after extraction of the juice, called apple pomaceis the solid residue that remains after milling and pressing of apples for cider, apple juice or puree production. It could be used as a livestock feed (Kafilzadeh et al., 2008).

The dried apple pomace contains 7 percent crude protein and 5 percent ether extract. It has 1.86 Mcal metabolizable energy per each $\mathrm{kg}$ DM and $1.12 \mathrm{Mcal}$ net energy (NE)/kg DM for lactating dairy cows (NRC, 2001). The ensiled apple pomace,incorporated up to 30 percent in the diet oflactating multiparous Holstein cows, did not show any adverse effects on milk yield orits composition (Ghoreishi, Pirmohammadi and Yansari, 2007). Alibes et al., (1984) showed that apples pomace and apple product could be included in diets containing alfalfa hay and soya bean meal as supplements. Gasa et al., (1992) reported that ensiled apple pomace could be safely incorporated in roughage diets that were properly supplemented with degradable nitrogen. Some researchers have reported data suggesting that structural carbohydrates can also be used as substrate for micro-organisms during ensiling (McDonald et al., 1991; Yahaya et al., 2000). Fang et al., (2016) indicate that feeding fermented apple pomace to finishing pigs increases the feed efficiency and affects the meat quality and fatty acid composition of back fat. Fayed (2016) conclude that replacement of berseem hay with apple pomac silage up to 50 percent in the diets of dairy goats could improve milk yield and composition without any adverse effect on their performance. 
Contamination of food and agricultural commodities by various types of toxigenic molds (fungi) is a serious and a widely neglected problem. Patulin is a mycotoxin produced by several species of Penicillium, Aspergillus and Byssochlamys molds that may grow on a variety of grains and fruits. The presence of residual patulin in apple juice shows as an indicator of the quality of fruit used in its production since an appreciable concentration of the mycotoxin remains in product after processing.

It is also reported to be present in silage intended for ruminants and it has been reported to be responsible for the deaths of cattle. Schneweis et al., (2000) reported that lower concentrations of patulin found in silage will rarely cause the typical neurotoxic signs in animals, but might exert detrimental effects on the rumen microflora, mainly because of its antimicrobial activity. Diazinon is an organophosphate insecticide with agricultural, commercial, and household uses.

It is used in agriculture to control insects on fruit and crops. Feeding Diazinon to pregnant animals has caused a decrease in the endurance,coordination, and growth of their offspring. In addition, the sexual development of offspring of both sexes wasdelayed. Diazinon also has caused reproductiveproblems in animals. Dogs fed Diazinon developed atrophied testicles.

There is no publicly available informationabout the reproductive effects of commercial Diazinon containing products on other animals. Therefore, the aim of the current experiment was to explore the effect of apple pomac silage as fodder source and residual pesticides determination on performance and residues of toxins in milk and some rumen fermentation in Mahabadi lactation goats in early lactation period.

\section{Materials and Methods}

This experiment was carried out at the goat barn of Urmia University in Iran. The effects of apple pomac silage on milk yield, milk composition and some nutrients digestibility were measured using 30 multiparous early lactating Mahabadi goats. They were held in individual stalls and the normal herd management practices were followed during the experiment.

The iso-caleric and iso-energetic dietary treatments were formulated according to the nutrition requirements for Sheep and Goats (NRC, 2007) guidelines by small ruminant nutrition system software (SRNS) version 1.9 .4468 with constant amounts of dry alfalfa, corn silage, soybean meal, barley and apple pomac silage. The treatments were control include apple pomac silage with no add-ons. The second treatment using microwave (900 watts and frequency $2450 \mathrm{MHz}$ for 20 minutes), in the third treatment, $50 \mathrm{~g}$ of "Mycofix-Plus" absorbent supplement per each goat was used and in the 4 and 5 treatments "Bio-Tox" absorbent supplement and"Bio-Acid" acidifier per ton of apple pomac silage were used respectively. The experimental diets in the form of a total mixed ration TMR were givendaily in two equal feeds at 08:00 and 16:00 $\mathrm{h}$.

\section{Analysis the chemical composition}

Dry samples were analyzed for ash (no. 942.05, AOAC 1990) and total N as Kjeldahl N (no. 954.01, AOAC 1990). Neutral detergent fiber (NDF) acid detergent fiber (ADF) and ADL fractions were determined by the detergent procedures of Robertson and Van Soest (1981) and Van Soest et al., (1991) without the use of sodium sulphite. Neutral detergent fiber and acid detergent fiber were expressed exclusive of residual ash. The acid detergent insoluble nitrogen (ADIN) was determined according to Goering and Van Soest (1970). Non fiber carbohydrates (NFC) were calculated according to NRC (2001).

\section{Dry matter intake measurement}

The amount of dry matter consumed was measured by taking into account the amount of dry matter left in the feeder and the amount of dry matter consumed daily.

\section{Evaluation apparent digestibility of nutrients, organic matter and dry matter}

To evaluate the digestibility of nutrients, during the 25 to 28 days of the experiment (for 4 days), the amount of feed consumed and the total feces and the feed remaining per day were measured.

$100 \mathrm{~g}$ from food and stool residues per each day was placed inside the nylon bags, and the samples were mixed together and dried in the oven at $60^{\circ} \mathrm{C}$ for 48 hours. Dry matter, crude protein and crude fat of feed samples were evaluated according to the method described by (Van Keulen and Young 1977). Finally, the apparent digestibility of nutrients was determined using acid insoluble ash as an internal marker described by (McDonald et I., 1990).

\section{Patulin and diazinon determination}

Determination of Patulin and Diazinon from apple pomac was performed by high performance liquid chromatography model Agilent1200. Steps of method for Patulin and Diazinondetermination included: Preparations of test sample, sample extraction, extract purification, extractevaporation to dryness, residue re-dissolution, HPLCdetection of Patulin and Diazinon. Patulinand Diazinon extraction was achieved in acetonitrile, andpurification of the obtained extract, using cleanup (C.U.) Patulin and Diazinon columns (MycoSep $R 228)$.

\section{Statistical analysis}

Data were analyzed in a form of completed randomized design, with five treatments and three replications each, by the general linear models procedure of SAS (2000). When significant differences occurred, Duncan test was used to compare means at level of $(\mathrm{P} \leq 0.05)$.

\section{Results}

The results of ruminal protozoal population means among different treatments are presented in the Table 1 . As result revealed that there were no significant differences about $\mathrm{pH}$ changes between treatments. The protozoa population tended to decrease and ammonia nitrogen has increased significantly in different treatments $(P \leq 0.05)$. 
Table 1. Effect of experimental treatments on $\mathrm{pH}$, protozoa and ruminal ammonia nitrogen concentration.

\begin{tabular}{cccc}
\hline Treatments & $\mathbf{p H}$ & $\begin{array}{c}\text { Protozoa population } \\
(\mathbf{m l . 1 0 - 5 )}\end{array}$ & $\begin{array}{c}\text { Ammonia nitrogen (mg.d) } \\
16.22^{\mathrm{ab}} *\end{array}$ \\
2 & 6.42 & $16.20^{\mathrm{a}}$ & $21.42^{\mathrm{dc}}$ \\
$21.68^{\mathrm{c}}$ \\
3 & 6.48 & $16.11^{\mathrm{a}}$ & $22.12^{\mathrm{a}}$ \\
4 & 6.50 & $16.18^{\mathrm{b}}$ & $21.76^{\mathrm{bc}}$ \\
5 & 6.36 & $16.18^{\mathrm{c}}$ & $21.90^{\mathrm{b}}$ \\
P-value & 6.08 & 0.221 & 0.001 \\
SEM & 0.001 & 0.015 & 0.065 \\
\hline
\end{tabular}

$*_{a, b, c}$ Means within rows with different superscripts are significantly different $(P \leq 0.05)$.

According to the increase of volatile fatty acids production, the proportion of acetatenot differed even though that of Propionate and iso-butyrateincreased but none significantly. The molar ratios of acetate and propionate and iso-butyratein the goats rumen containing apple pomace was differed in respect to the availability for fermentation by rumen microflora. It was suggested that the progress of fermentation about four substrates by the rumen microflora was influenced by the amount of sugar, especially reducing sugar in apple pomace substrates (Tables 2 and 3 ).

Table 2. Effect of experimental treatments on ruminal fatty acids concentration.

\begin{tabular}{cccccc}
\hline Treatments & $\begin{array}{c}\text { Total fatty acids } \\
\mathbf{( L / m m o l )}\end{array}$ & $\begin{array}{c}\text { Acetate } \\
\mathbf{( \% )} \\
\mathbf{m o l a r})\end{array}$ & $\begin{array}{c}\text { Propionate and } \\
\text { isobutyrate } \\
\mathbf{( \% )}\end{array}$ & $\begin{array}{c}\text { Butyrate } \\
\mathbf{( \% )}\end{array}$ & $\begin{array}{c}\text { Valerate } \\
\mathbf{( \% )}\end{array}$ \\
1 & $91.27 \mathrm{~d} *$ & 61.25 & 21.66 & $13.90 \mathrm{e}$ & 2.15 \\
2 & $91.80 \mathrm{c}$ & 60.59 & 22.68 & $15.39 \mathrm{~b}$ & 2.19 \\
3 & $93.17 \mathrm{a}$ & 60.80 & 23.50 & $15.87 \mathrm{a}$ & 2.13 \\
4 & $90.63 \mathrm{e}$ & 61.03 & 24.00 & $14.77 \mathrm{c}$ & 2.14 \\
5 & $92.71 \mathrm{~b}$ & 61.33 & 24.24 & $14.60 \mathrm{~d}$ & 2.13 \\
P-value & 0.001 & 0.606 & 0.058 & 0.001 & 0.11 \\
SEM & 0.24 & 0.15 & 0.33 & 0.23 & 0.073 \\
\hline
\end{tabular}

$*_{a, b, c}$ Means within rows with different superscripts are significantly different $(P \leq 0.05)$.

Table 3. The amount ofresidualedimidacloprid toxin measured in different treatments.

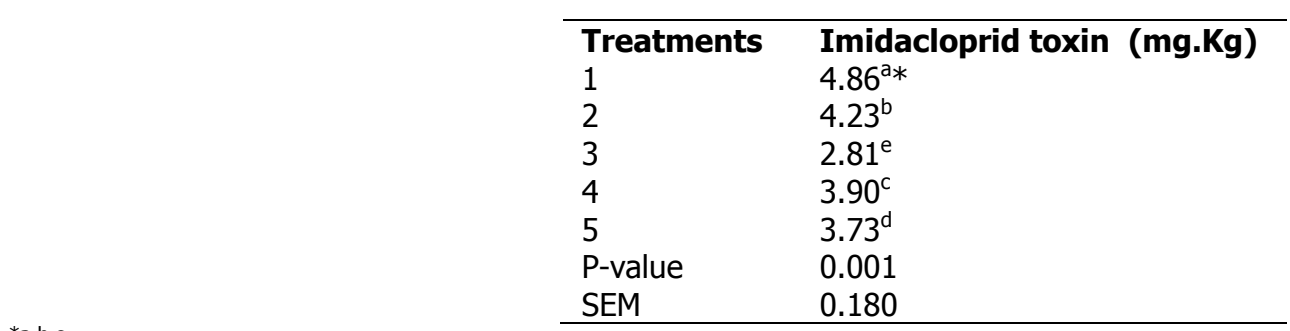

$*_{a, b, c}$ Means within rows with different superscripts are significantly different $(P \leq 0.05)$.

\section{Discussion}

Results of this study suggest that apple pomace can improve the performance,protozoa populationand ammonia nitrogen of experimental goats. There was no significant difference within treatments apple pomace mixed silage had no effect on dairy goat's average daily feed intake.

Shalini et al., (2010) indicated that apple pomace is used fresh in the vicinity of apple processing plants. Because of its high moisture and high content in fermentable sugars, fresh apple pomace spoils readily and is often ensiled or dehydrated for longer preservation. Zhang et al., (2016) mentioned that unfermented apple pomace lead to better performance, daily gain, feed return and net meat rate in experimental sheep

Fontenot et al. (1977) reported that the mortality of calves and abortion rate of cows may increase if apple pomace is over fed. If too much apple pomace is fed, it may be required to supply more protein, particularly for the growing animals.

Romero-Huelvaand Molina-Alcaide, (2013) mentioned that the ruminal pH is one of the most important factorsaffecting the fermentation and influences its functions and it varies depending on the type of the diets. Increasing the final $\mathrm{pH}$ of rumen environment without changes in final ammonianitrogen concentration substrate degradability and totalvolatile fatty acidproduction (2013). Rumsey (1978) reported that feeding apple was associated with a slightly reduction of ruminal $\mathrm{pH}$, a higher acetic to propionic acid ratio and lower proportions of ruminal branchedchain fatty acids. Additionally (Oltjen et al., 1977) observed that the lower $\mathrm{pH}$ in diets containing apple might be due to the high content of acids components of apple pomace,especially malic and citric acid. Pirmohammadi et al., (2006) showed apple pomace mixed silage replaced $65 \%$ corn silage could significantly increase the average milk yield per day, but had no significant effect on blood biochemical indexes, ruminal pH values and ammonia nitrogen concentration.

Ahn et al., (2002) concluded that replacement of concentrates with apple pomace in the rice straw based diets of Korean native goats given separately or by pre-mixing gave satisfactory results of feed intake, digestibility, $\mathrm{pH}$ of ruminal fluid and production of $\mathrm{NH}_{3}-\mathrm{N}$ and VFA in the rumen. 
Fu et al. (2001) reported that rumendegradable protein (RDP) was less required for none starch carbohydrates (NSC) fermenting bacteria than that found in many usual diets and itcould indicate the rumen microbial population in thegoats fed apple pomace was more efficient at scavengingnitrogen from the feed than control.

Paryad andRashidi, (2009) indicated that the more retention of nitrogen in sheep fedsome by product pomace can explain by reduced ammoniaconcentrations in the rumen that appeared to result fromincreased incorporation of ammonia into microbial proteinthat probably were the direct result of stimulated microbial activity.

Romero-Huelvaand Molina-Alcaide, (2013) showed that the increasing rumen volatile fatty acids levels and decreased ruminal ammonia nitrogenin Granadina goats were fed by tomato pomace comparison with the control groups.

The reduction of ammonia nitrogen in the rumen liquor appears to be the result of increased incorporation of ammonia nitrogen into microbial protein and it was considered as an important result to stimulated microbial activity (Romero-Huelvaand Molina-Alcaide, 2013). Additionally supplementation of more fermentable carbohydrate to ruminant rations causes a decrease in rumen ammonia probably due to a greater uptake of ammonia by rumen microorganisms in support of enhanced microbial growth (Tagari et al., 1964). Schauff and Clark, (1992) showed that although acetate concentration in the rumen of goats fed $60 \%$ apple pomace diet was in a decreasing trendcompared to the others. They also indicated that, ruminal ammonia nitrogen $\left(\mathrm{NH}_{3}-\mathrm{N}\right)$ may have been used moreefficiently for the production of microbial protein due togreater energy intake which would provide for greaterenergy fermented in the rumen of goats given apple pomace. Acetate to propionate ratio was reduced in diets with thehigher levels of apple pomace, likely a consequence of thehigher NSC of these diets.

\section{Conclusion}

In regard to this information, the inclusion of apple pomace silage in experimental goat's diet was associated with a slight lower rumen $\mathrm{pH}$, higher concentration of acetate and propionate and total volatile fatty acids in rumen. The potential value of byproducts in animal feeding and better dry matter and organic matter digestibilitydepends on their nutritive characteristics. But the livestock producers are responsible for ensuring that the animals and products that they market do not contain unacceptable chemical residues. Anyone intending to feed waste materials to ruminant animals such as cattle, sheep and goatsor to pigs must ensure that it is free of prohibited or restricted substances.

\section{References}

Abd-El-Ghaney A, 2002. Study the effect of imidacloprid insecticide on some physiological parameters in Japanese quail. Thesis for M.Sc. Faculty of science Al-Azhar University for (girls).

Abdollahzadeh F, Pirmohammadi R, Fatehi Fand Bernousi I, 2010. Effect of feeding ensiled mixed tomato and apple pomac on performance of Holstein dairy cows. Slovak J AnimSci 43 (1): 31- 35.

AOAC, 1990. Official methods of analysis. 15th edn. Association of Official Analytical Chemists, Washington DC.

Bajwa U and Sandhu KS, 2011. Effect of handlingand processing on pesticide residues in Food-a review. J Food Sci Techno 5: 1-20. BioTox, 2017. Mycotoxins binders, Baltivet.htm.

Bluett SJ, Thom ER, Clark DA, MCDonald KA and Minnie EMK, 2003. Milk solids production from cows grazing perennial ryegrasscontaining AR1 or wild endophyte. Proc New Zealand GrasslandAssociation 65: 83-90.

Bonnechère A, Hanot V, Jolie $R$, Hendrickx $M$, Bragard C and Bedoret $T$, 2012a. Effect of household and industrial processing on levels of five pesticide residues and two degradation products in spinach. $J$ of Food Cont 25: 397-406.

Bonnechère A, Hanot V, Jolie R, Hendrickx M, Bragard C, Bedoret T, and Van Loco, J, 2012b. Processing Factors of Several Pesticides and Degradation Products in Carrots by Household and Industrial Processing. J of Food Res 3: 68-83.

Ceron JJ, Panizo CG. and Montez A, 1995. Toxicological effects in rabbits induced by endosulfan, lindane and methyl parthion representing agricultural by products contamination Bayer. 48 (66): 105-110.

CFR, Code of Federal Regulations, 2017. Imidacloprid tolerances for residues http://www.lawschool.cornell.edu. 40 CFR 180.472.

Chen M, Tao L, McLean J, and Lu C, 2014. Quantitative analysis of neonicotinoid insecticide residues in foods: implication for dietary exposure. J of Agric and Food Chem. Just Accepted Manuscript.

Coombe J B, Wardrop I D and Tribe D E, 1960. A study of milk production of the grazing ewe, with emphasis on the experimental technique employed. J of Agric Sci. 353-359.

Darko G, Acquaah SO, 2008. Levels of organochloride pesticidesresidues in dairy products in Kumasi, Ghana. Chemosphere, 71: 294-298.

EFSA Panel on Additives and Products or Substances used in Animal Feed (FEEDAP), 2011. Scientific Opinion on the safety and efficacy of bentonite (Dioctahedral montmorillonite) as feed additive for all species. European Food Safety Authority (EFSA). EFSA Journal 9 (2): 1-24

Erwin E, Elam C, Dyer I, 1997. The influence of sodium bentonite in vitro and in the ration of steers. J AnimSci 16: 858-862.

Kafilzadeh F, Tassoli G, Maleki A, 2008. Kinetics of digestion and fermentation of apple pomace from juice and puree making. Res J BiolSci, 3 (10): 1143-1146.

Juliet S, Mandal TK, Mai B, Chowdhury A, Bhattacharyya A and Chakraborty AK, 1998. Metabolic study of isoproturon in goats following a single oral administration: toxicokinetics and recovery. J Agric Food Chem., 46: 178-183.

Kapoor U, Srivastava MK, Srivastava AK, Patel D K, Garg V, and Srivastava L P, 2012. Analysis of imidacloprid residues in fruits, vegetables, cereals, fruit juices and baby foods and daily intake estimation in and around lucknow, India. J of Envir Toxic and Chem, DOI. 10.1002/etc.2104.

Kazemi M, Tahmasbi A M, Valizadeh R, and Naserian AA, 2012a. Toxic influence of diazinon as an organophosphate pesticide on parameters of dry matter degradability according to in situ technique. J of Basic and Applied Sciences, 12 (06): $229-233$.

Kazemi M, Tahmasbi AM., Valizadeh R, Naserian AA, and Soni A, 2012b. Organophosphate pesticides: A general review. Agric Sci Res Journals 2 (9): 512- 522.

Kazemi M, Tahmasbi AM, Valizadeh R, Naserian AA, and Sonei A, 2013. Toxicological effects of diazinon as an organophosphate pesticide on fermentation activity of microorganisms and evaluation of sodium bentonite as a toxin binder by using the in vitro batch culture. J of Agric and Food Sci, 1 (4): 52-58.

Kim YY, Kil DY, Oh HK, and Han In K, 2004. Acidifier as an Alternative Material to Antibiotics in Animal Feed. 3rd International Symposium on Recent Advances in Animal Nutrition. Pp. 1084-1059. Proceeding of 11th Animal Sciences Congress, AsianAustralasian Association of Animal Production Societies. Kuala Lumpur, Malaysia. 
Kiyothong K, Roelinson P, Wanapat M, and Khampa S, 2012. Effect of mycotoxin deactivator product supplementation on dairy cows. J of Anim Prod Sci 52:832-841.

Kollosova A, Stroka J, Breidbach A, Kroeger K, Ambrosio M, Bouten K, and Ulberth F, 2009. Evaluation of the Effect of Mycotoxin Binders in Animal Feed on the Analytical Performance of Standardised Methods for the Determination of Mycotoxins in Feed. Joint Research Centre (JRC) scientific and technical reports. EUR 23997 EN. DOI 10.2787/15352.

Kutches AJ, Church DC and Duryee FL, 1970. Toxicological effects ofpesticides on rumen function in vitro. J Agr Food Chem, 18 (3):430-433.

Latif Y, Sherazi TH, and Bhanger MI, 2011. Assessment of Pesticide Residues in Some Fruits Using Gas Chromatography Coupled withMicro Electron Capture Detector. Pak J Anal Environ Chem. 12 (1): 76-87.

Lukstadt C, 2014. Acidifiers in animal nutrition a guide for feed preservation and acidification to promote animal performance. Published in: Technology, Business, Nottingham University Press

Morales $\mathrm{H}$, Marin S, Rovira A, Ramos AJ, and sanchis V, 2006. Patulin accumulation in apples by Penicillium expansum during postharvest stages. Letters in Applied Microbiology. doi:10.1111/j.1472-765X.2006.02035.x.

Morgavi DP, Boudra H, Jouany JP, and Graviou D, 2003. Prevention of patulin toxicity on rumen microbial fermentation by SH containing reducing agents.

J of Agric and Food Chem, 51: 6906-6910.

Nagahi N, Salimi M, Mirhadi V, and Behbood V, 1995. Study on the application of apple pomace in sheep nutrition. Animal Science Research Institue of Iran, Research Magazine, 73: 25-29.

National Registration Authority for agricultural and veterinary chemicals (NRA), 2011. Public release document, Imidacloprid in the product confidor insecticide. National Research Council (NRC), 2007. Nutrient Requirements of Small Ruminants Sheep, Goats, Cervids, and new world camelids. Washington, D. C.

National Research Council (NRC), 2001. Nutrient requirements of dairy cattle, 7th edition, National AcademyPress, Washington DC, USA.

Peniche G I, Sarmiento F L and Santos R R, 2015. Estimation of milk production in hair ewes by two methods of measurement. Revista MVZ Cordoba. 20 (2): 4629-4635.

Raikwar MK, and Nag SK, 2003. Organochlorine pesticide residues in animal feeds. In: Proceedings of 40th Annual Convention of Chemists. J of Indian Chemical Society, p. D4.

Schorder JW, 1999. By product and regionally available alternative feedstuff for dairy cattle. NDSU Animal and Rangescience.

Sharma HR, Kaushik A and Kaushik CP, 2007. Pesticide residues in bovine milk from a predominantly agricultural state of Haryana, India. Environ Monit Assess. 129: 349-357.

Tapia MO, Stern MD, Koski RL, Bach A, and Murphy MJ, 2002. Effects of patulin on rumen microbial fermentation in continuous culture fermenters. J of Anim Feed Sci and Tech, 97 (3): 239-246.

Valentine SC, Bartsch BD and Carroll PD, 1993. Production and composition ofmilk by dairy cattle grazing high and low endophyte cultivars of perennialryegrass. Pp. 138-141. Proceedings of the 2nd international symposium onAcremonium/grass interactions. Palmerston North, New Zealand.

Van Soest PJ, Robertson JB and Lewis BA, 1991. Methods of dietary fiber, neutral detergent fiberand non-starch polysaccharides in relation to animal nutrition. J Dairy Sci 74 (10): 3583-3597.

Mc Donald PR, Edwards A, and Greenhalgh, JFD, 1990. Animal Nutition. 4th edition published in the united states with John wiley and Sons, Inc, NewYork.

Schauff, D. J. and J. H. Clark. 1992. Effects of feeding dietscontaining calcium salts of long-chain fatty acids to lactatingdairy cow. J. Dairy Sci. 75:2990.

Fontenot, J. P., K. P. Bovard, R. R. Oltjen, T. S. Rumsey and B. M. Priode. 1977. Supplementation of apple pomace with nonprotein nitrogen for gestating beef cows. I. Feed intake andperformance. J. Anim. Sci. 45:513-522.

Fu, C. J., E. E. D. Felton, J. W. Lehmkuhler and M. S. Kerley.2001. Ruminal peptide concentration required to optimizemicrobial growth and efficiency. J. Anim. Sci. 79:1305-1312.

Ahn. J. H., Jo. I. H and Lee, J. S. 2002. The use of apple pomace in rice straw based diets of Korean native goats (Capra Hircus). Asian-Aust. J. Anim. SciVol 15, No. 11: 1599-1605.

Oltjen R.R. Rumsey T.S. Fontenot J.P. Bovaid K.P. Priode B.M. 1977 Supplementation of apple pomace with non protein nitrogen for gestating beef cows. III. Metabolic parameters J. Anim. Sci 45532542

Zhang, Z., Yang. Z, Cui, B and Li, Y. 2016. Effects of adding fermented apple pomace in diets on the fattening of Tan Lamb. Journal of Anhui Agricultural Sciences.79-80.

Tagari, H., Y. Driori, L. Ascarelli and A. Bondi, 1964. The influence of level of protein and starch in rationsfor sheep on utilization of protein. British Journal ofNutrition, 18: 333.

Romero-Huelva, M. and E. Molina-Alcaide. 2013. Nutrient utilization, ruminal fermentation, microbialnitrogen flow, microbial abundances and methaneemissions in goats fed diets including tomato andcucumber waste fruits. Journal of Animal Science,91 (2): 914-923.

Paryad, A. and M. Rashidi, 2009. Effect of yeast (Saccharomyces cerevisiae) on apparent digestibilityand nitrogen retention of tomato pomace in sheep. Pakistan Journal of Nutrition, 8: 273-278.

Pirmohammadi, Y. Rouzbehan, K. Rezayazdi, and M. Zahedifar. 2006. The chemical composition, digestibility and in situ degradability of driedand ensiled apple pomace and maize silage. Small Ruminant Research, 66, 150-155.

\section{Citation:}

Gharehbagh, A.G., Pirmohammadi, R., Alijoo, Y.A., Behroozyar H.K. (2020) Investigating the effect of apple pomacsilage as fodder sourceon performance and residues of its toxins in milk and some rumen fermentation in Mahabadi lactation goats in early lactation period. Ukrainian Journal of Ecology, 10 (1), 241-245.

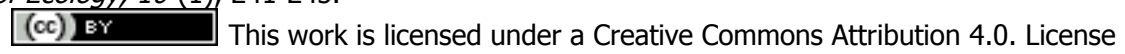

